\author{
Ray \& Elizabeth Partridge* \\ London, United Kingdom
}

\title{
Marital Spirituality - The Centre of Family Spirituality
}

\section{Introduction}

We approach the subjects of Marital and Family Spirituality from a background of experience in the pastoral fields of marriage preparation, marriage support and family life of some thirty five years.

* Rev. RAY \& ELIZABETH PARTRIDGE - After marrying in 1970 Ray and Elizabeth Partridge discovered a shared closet desire to be of service in the third world and volunteered as lay missionaries to Papua New Guinea, Elizabeth making use of her teaching qualifications and Ray adapting from his mechanical engineering background to teach commerce, both in a Catholic secondary school. After two years we returned to the UK and became involved in the Worldwide Marriage Encounter movement as weekend presenters and regional leaders, working in that apostolate until 1984. We then founded Catholic Video Education to produce catechetical videos including a marriage preparation course that sold to many of the Catholic parishes of England and Wales. In 1993 Ray retired from his engineering career and we became founder members of a community shared by Augustinian Friars and laity to run Clare Priory in Suffolk as a retreat house. During this time we both studied for an MA in personal, moral and spiritual development in a theological background. On return to our own home in Hythe on the South coast of England some 4 years later we embedded ourselves in the local community as catechists for marriage preparation and the Rite of Christian Initiation. Elizabeth studied to become a therapeutic counsellor and Ray undertook formation for the permanent diaconate, being ordained in 2001. From 2002 until 2013 we served as marriage and family life coordinators 
We start with a review of what the conciliar documents of the Second Vatican Council and Post Conciliar documents have to say about Family Spirituality and Marital Spirituality. We will then attempt to establish a definition of Marital Spirituality that has a resonance with the experiences of married life and relate that definition to the way in which Marital Spirituality is a vital component of the spirituality of the family.

Family spirituality can only be examined in the context of an accepted definition of what constitutes family. There is no doubt that the ideal put forward by the Church is that family is a sacramentally married man and woman with their own children. There are of course many other circumstances under which children are brought up which in itself raises questions about whether the ideal is matched by the facts and whether, in order to sustain the ideal, all other possibilities should be considered outside the ideal of family. However to exclude what is becoming an increasingly large minority proposes an elitist attitude that cannot be just towards the children thus affected.

Perhaps the broadest possible definition of family is required in order to deal justly with the subject of family spirituality, that it is any combination of children and adults where the adults have assumed the responsibility for the raising and forming of the children. This definition would include single parent families and also the recent phenomena of children being adopted by same sex partnerships. However this present work concentrates on the ideal and focuses on marital spirituality as the centre of family spirituality.

The subject of family spirituality was raised to prominence by the Second Vatican Council and the importance of it and has been emphasised in a number of documents since. In coining the term "Domestic Church"1 Lumen Gentium set the standard for the responsibilities of parents in relationship to passing on the faith to their children and encouraging them into the growth that is proper to each of them. Family spirituality is alluded to in Apostolicam Actuositatem ${ }^{2}$ in

for the Kent Pastoral Area in the diocese of Southwark, some 51 parishes scattered in a largely rural area. We have two adopted children and seven grandchildren.

1 Dogmatic Constitution Lumen Gentium 11 (1964); available from http://www.vatican.va/ archive/hist_councils/ii_vatican_council/documents/vat-ii_const_19641121_lumen-gentium_en.html (20.01.2014).

2 Pope Paul VI, Apostolicam Actuositatem 30 (1965); available from http://www.vatican.va/ archive/hist_councils/ii_vatican_council/documents/vat-ii_decree_19651118_apostolicamactuositatem_en.html (20.01.2104). 
the sense of parental responsibility for ensuring that their children participate in the mission of the Church to spread the Good News of God's love for all people, a perspective that is reiterated in Evangelii Nuntiandi ${ }^{3}$ in speaking of the duty of families to participate in evangelisation. In Familiaris Consortio the significance and centrality of the Sacrament of Marriage are emphasised as the key to family spirituality. Spouses are bound together in their Sacrament as Christ is bound to the Church and are called to sacrifice for each other as the Redeemer sacrificed himself, the Sacrament being a real symbol of the event of salvation. They are called to a deep personal unity that leads "beyond one flesh," to "forming one heart and soul" . Much earlier in Casti Conubi Pope Pius XI said of Sacramental marriage, "the souls of the contracting parties are joined and knit together more directly and more intimately than are their bodies, and that not by any passing affection of sense of spirit, but by a deliberate and firm act of the will; and from this union of souls by God's decree, a sacred and inviolable bond arises" . "The human family, disunited by sin, is reconstituted in its unity by the redemptive power of the death and Resurrection of Christ. Christian marriage, by participating in the salvific efficacy of this event, constitutes the natural setting in which the human person is introduced into the great family of the Church" domestic Church" by virtue of the presence of the Holy Spirit as it "constitutes a specific revelation and realization of ecclesial communion"7. The Sacrament gives to husband and wife power to live out their covenanted commitment to each other and as parents they are empowered to live their vocation ${ }^{8}$. Sacramental marriage fortifies the spouses and consecrates them and gives them the grace needed to

3 Pope Paul VI, Evangelii Nuntiandi 71 (1975); available from http://www.vatican.va/holy_father/ paul_vi/apost_exhortations/documents/hf_p-vi_exh_19751208_evangelii-nuntiandi_en.html (20.01.2014).

4 John Paul II, Apostolic Exhortation Familiaris Consortio 13 (1981); available from http://www. vatican.va/holy_father/john_paul_ii/apost_exhortations/documents/hf_jp-ii_exh_19811122_familiarisconsortio_en.html (17.12.2013).

5 Pius XI, Casti Conubi 7 (1930); available from http://www.vatican.va/holy_father/pius_xi/ encyclicals/documents/hf_p-xi_enc_31121930_casti-connubii_en.html (20.01.2014).

6 John Paul II, Apostolic Exhortation Familiaris Consortio 15 (1981); available from http://www. vatican.va/holy_father/john_paul_ii/apost_exhortations/documents/hf_jp-ii_exh_19811122_familiarisconsortio_en.html (17.12.2013).

7 John Paul II, Apostolic Exhortation Familiaris Consortio 21.

8 John Paul II, Apostolic Exhortation Familiaris Consortio 47. 
live out an authentic spirituality themselves and with their children "that draws its inspiration from the themes of creation, covenant, cross, resurrection". The grace that married couples and families receive by virtue of the Sacrament "must be placed at the service of the building up of the Church, the establishing of the Kingdom of God in history" ${ }^{10}$. Focusing on difficult cases Familiaris Consortio summaries this message, originating from the Synod Fathers, "it is easier to help people understand and live the lofty aspects of the spirituality of marriage and the family, aspects which take their inspiration from the value of Christ's Cross and Resurrection, the source of sanctification and profound happiness in daily life, in the light of the great eschatological realities of eternal life"11. This statement does not apply only to difficult cases and we will return to the theme of the Paschal Mystery later.

Ordinary family life can, from some perspectives have little to do with marital and family spirituality and yet the daily activity of work, mental and physical relaxation and the ordinary communications and decision taking necessary, even in difficult circumstances, are spiritual sacrifices acceptable to God ${ }^{12}$. These day to day events are ways in which the faithful married and families participate in the life of the Church as Communion when they are orientated towards Jesus Christ and His Church ${ }^{13}$. The renewal of the vocation of the Sacrament of Marriage is one of the keys to bringing about a greater charity towards all, an encouragement to conversion to the Christian life and an invitation to the baptized who have fallen away to return to communion in the Church ${ }^{14}$.

The grace of the Holy Spirit received through the Sacrament of Marriage can be described as holy power, the power of the Holy Spirit to strengthen the spouses so they can remain faithful to their marriage covenant and fulfill the call of St Paul in Ephesians 5 to become one. This inner strength in turn strengthens the family and

\footnotetext{
9 John Paul II, Apostolic Exhortation Familiaris Consortio 56.

10 John Paul II, Apostolic Exhortation Familiaris Consortio 71.

11 John Paul II, Apostolic Exhortation Familiaris Consortio 77.

12 John Paul II, Christifideles Laici 14 (1988); available from http://www.vatican.va/holy_father/ john_paul_ii/apost_exhortations/documents/hf_jp-ii_exh_30121988_christifideles-laici_en.html (17.12.2013).

13 John Paul II, Christifideles Laici 18.

14 John Paul II, Christifideles Laici 30.
} 
helps to forge unity within the family itself ${ }^{15}$. Marriage is so rooted in the plan of God that "without this truth, the life of the spouses and the family will not succeed in attaining a fully human meaning"16.

The Sacrament of Marriage is intrinsically linked to the Eucharist in the parallel drawn by St Paul (Eph 5:31-32) with the Eucharistic unity of Christ with His Church, the Bridegroom and His Bride ${ }^{17}$. This alone justifies the teaching of the Church on the indissolubility of marriage as Christ's love for His Church is total and unconditional as prefigured by the prophets, principally by Jeremiah in the Old Testament in the reiterated expression, "You shall be my people and I will be your God"18.

\section{Models of Family}

In 2004 the Bishop's Conference of England and Wales issued a questionnaire aimed at finding out contemporary views of the laity on marriage and family life. This was a qualitative survey but nevertheless there were some clear outcomes with a large number of respondents reporting similar answers. For example:

"We heard of a culture that is child-centred and which therefore encourages parents to be child-centred. With both parents working, what little leisure time there is often centres on being together as a family, pushing the couple relationship, if there is one, to the back burner. Yet parents naturally prioritise their children's welfare as their primary responsibility. One couple referred to their children as their joint 'life project', which suggests that they viewed bringing up their children as something which enhanced their relationship. Certainly time together as a family was highly prized" 19 .

15 John Paul II, Gratissimam Sane 4 (1994); available from http://www.vatican.va/holy_father/ john_paul_ii/letters/1994/documents/hf_jp-ii_let_02021994_families_en.html (20.01.2014).

16 John Paul II, Gratissimam Sane 11.

17 Benedict XVI, Sacramentum Caritatis 28,29 (2007); available from http://www.vatican.va/ holy_father/benedict_xvi/apost_exhortations/documents/hf_ben-xvi_exh_20070222_sacramentumcaritatis_en.html (20.01.2014).

18 Jer $11: 14,31: 22$, 36:38: See also Gen 17:8; Ex 6:7; Lev 26:12; Is $41: 13$; Jer 7:23; Zech 8:8.

19 Catholic Bishops' conference of England and Wales, Not Easy But Full of Meaning Catholic Family Life in 2004, Redemptorist Publications, Alphonsus House, Chawton, Hampshire 2005, 27. 
If we imagine the family to be shaped like a bicycle wheel with the hub and rim forming the major components and the spokes being the spiritual, emotional and physical ties that bind the wheel together we can consider two different arrangements. In the first the spouses form the hub with the children forming the rim. In this model the children can be seen as the product of the relationship of the spouses the integrity of the whole being sustained by the spokes.

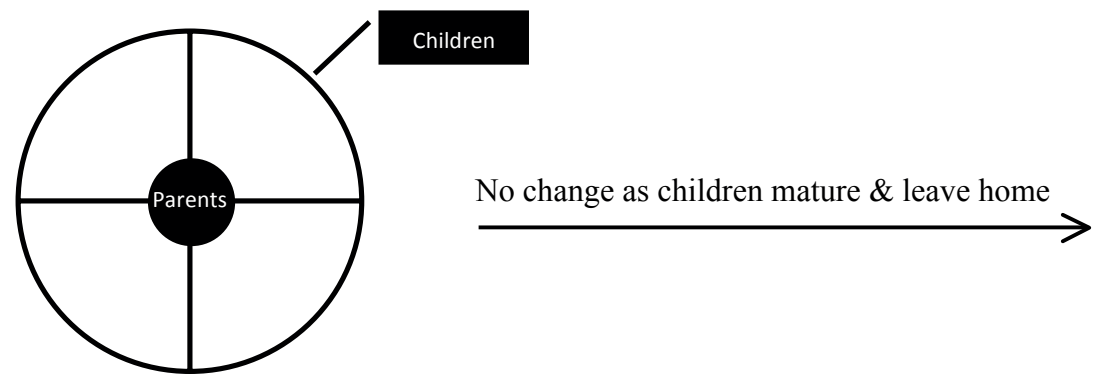

As the children grow up, become independent and eventually leave the family home the wheel's integrity is sustained by the spouses at the centre and, however distant the children may become, physically, spiritually or emotionally, the hub remains secure as the focal point of the family. In the second model the parents see the children as the hub, the centre of the family, and place themselves at the rim. As the children mature and become independent the hub is weakened until eventually the wheel no longer exists as a whole. This phenomenon is witnessed to by the number of marriages that break down once the children have moved away from the family home, because the focus of the spouses has not been their unity but on their children, resulting sometimes in the "Empty Nest Syndrome".

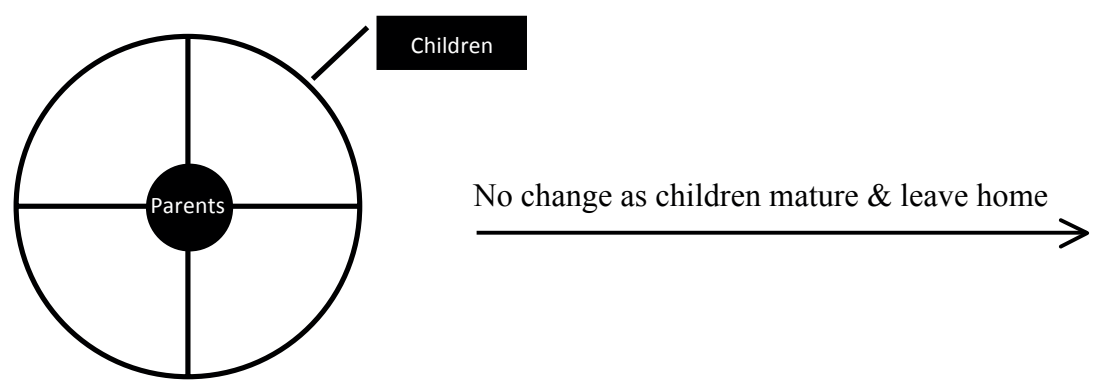

The "Empty Nest Syndrome" refers to feelings of depression, sadness, and/or grief experienced by parents and caregivers after children come of age and leave their childhood homes. This may occur when children go to college or get married. Women are more likely than men to be affected; often, when the nest is emptying, 
mothers are going through other significant life events as well, such as menopause or caring for elderly parents. Yet this doesn't mean that men are completely immune to Empty Nest Syndrome. Men can experience similar feelings of loss regarding the departure of their children ${ }^{20}$. Looked at from another perspective it could be said that the couple have focused on family spirituality to the exclusion, in the extreme case, of their marital spirituality.

It follows that family spirituality cannot be a substitute for marital spirituality and that the spiritual wellbeing of the spouses is very important to the spiritual wellbeing of the whole family. We therefore need to examine marital spirituality as the source of family spirituality, just as the spouses are the physical source of the family.

Considering the background to spiritualities in the Catholic Church, based so strongly on religious life, celibacy and consecrated virginity and cultural attitudes to men and women it is perhaps not so surprising that it took nearly 2 millennia from the time of Christ before the concept of spirituality of the married couple was seriously thought about ${ }^{21}$. In considering marriage the image presented by the magisterium generally moves quickly to family life and does not give adequate weight to marital spirituality ${ }^{22}$. Theological developments have pointed to a spirituality that is specific to married couples rather than from a celibate origin ${ }^{23}$. However opinions diverge as to what drives this spirituality, from it being based on sexuality ${ }^{24}$

20 Psycology Today; available from http://www.psychologytoday.com/conditions/empty-nestsyndrome (14.01.2014).

21 T. Knieps-Port le Roi, Marital Spirituality - The Emergence of a new Paradigm in the Theology of Marriage and in Christian Spirituality, in: T. Knieps-Port le Roi / M. Sandor (eds.), Companion to Marital Spirituality, Leuven 2008, Peeters, p. 25-34.

22 John Paul II, Apostolic Exhortation Familiaris Consortio (1981), 180 references to marriage, 540 references to family; available from http://www.vatican.va/holy_father/john_paul_ii/apost_ exhortations/documents/hf_jp-ii_exh_19811122_familiaris-consortio_en.html (17.12.2013); John Paul II, Gratissimam Sane (1994), 63 references to marriage, 360 references to family; available from http://www.vatican.va/holy_father/john_paul_ii/letters/1994/documents/hf_jp-ii_let_02021994_ families_en.html (17.12.2013).

23 T. Knieps-Port le Roi, Marital Spirituality - The Emergence of a new Paradigm in the Theology of Marriage and in Christian Spirituality, in: T. Knieps-Port le Roi / M. Sandor (eds.), Companion to Marital Spirituality, Leuven 2008, Peeters, p. 16-25.

24 John Paul II, The Theology of the Body: Christian Spirituality of Marriage Possible Only by Living According to the Spirit, "L'Osservatore Romano" (1979-1984), p. $319 \mathrm{ff}$. 
to it being centred on the human need for a spiritual context in contradiction to the more sustainable view that we are essentially spiritual beings ${ }^{25}$. Little seems to be expected of married couples ${ }^{26}$ the spiritual aspirations of celibates ${ }^{27}$ being seen as "higher" 28 . In Blessed John Paul II's "Theology of the Body" it is necessary to wade through much negativity and the importance of celibacy, for example the idea that celibacy for the sake of the kingdom is a higher calling that affirms marriage, with no mention of marriage for the sake of the kingdom ${ }^{29}$, before getting to any positivity regarding the couple's sexuality. Even then it is somewhat overshadowed by warnings about concupiscence ${ }^{30}$.

The intercessory prayers for priests and religious in the version of the Divine Office used in much of the English speaking world are directed at strengthening them in their religious and pastoral life whilst prayers for married couples are, in the main, for them to be helped in their difficulties and struggles ${ }^{31}$. The underlying message is that priesthood and religious life are OK but marriage is problematic. For example in the period from Ash Wednesday till Pentecost there are 17 positive prayers for priests and religious and none at all for marriage or family. Prayers that are negative about marriage and family outnumber positive prayers by a factor of three. One is left wondering if the attitudes suggested are still present and how many of those attitudes have been transmitted to students for the priesthood since publication of the Divine Office.

25 John Paul II, General Audience (16 ${ }^{\text {th }}$ April 1986), 2: available from http://www.vatican.va/ holy_father/john_paul_ii/audiences/1986/documents/hf_jp-ii_aud_19860416_it.html (18.12.2013); See also Pierre Teilhard de Chardin, Le Phénomène Humain: Paris 1956, Editions du Seuil, 'We are not human beings having a spiritual experience; we are spiritual beings having a human experience'; R. Gallardetz, A Daring Promise: A Spirituality of Christian Marriage, Liguori Missouri 2007, Liguori/ Triumph, p. 23-24.

261 Cor $7: 32-34$.

27 Mt 19:10-12.

28 Dogmatic Constitution Lumen Gentium (1964), 42; available from http://www.vatican.va/ archive/hist_councils/ii_vatican_council/documents/vat-ii_const_19641121_lumen-gentium_en.html (17.12.2013).

29 John Paul II, The Theology of the Body: Celibacy for the Kingdom affirms marriage, General Audience 5 May 1982, “L'Osservatore Romano" (1979-1984), p. $208 \mathrm{ff}$.

30 John Paul II, The Theology of the Body: Continence Protects the Dignity of the Conjugal Act, General Audience 24 1979-1984, October 1984, “L'Osservatore Romano", p. 312ff.

31 The Divine Office: Vols I-III, London 1974: Collins. 
Conventional theology also links marital spirituality with piety and prayer $^{32}$ but this does not consider the call to unity as being part of that spirituality which includes the whole of married life not only the pious practices and prayer of the couples. Blessed John Paul II spoke of prayer, penance and the Eucharist as the principle sources of spirituality for married couples ${ }^{33}$ but ignored the very obvious Sacrament of Marriage as a principle source. All the Sacraments are the ways in which the faithful receive the Holy Spirit to strengthen their lives. In their quest to achieve the unity to which the married are called surely the Sacrament of Marriage must be included as a major source of marital spirituality. Married life is very often heroically virtuous ${ }^{34}$ in the sacrifices made by husband and wife and it could be said that holiness in marriage is widespread but the experience of it is rarely understood or acknowledged.

None of the conciliar or post conciliar documents give an adequate definition of the spirituality of marriage or family. Perhaps because the history of spiritualities in the Church is linked so intimately with the ascetic and religious life with their specific rules there seems to have been few attempts to achieve a global definition. One attempt, that helps to point the way to a deeper understanding, is that of Professor Fr Robert Dodaro OSA, "spiritualities (in the plural) are windows on the truth" ${ }^{35}$. This can be applied equally to individuals as well as Sacramental couples but it suggests many spiritualities rather than a few, that the spirituality of each individual and therefore of each couple is unique. The ultimate spiritual goal of each believer is, of course, spiritual unity with Christ but in marriage the couple pledge themselves to seek unity with each other as a means towards achieving that goal.

The Worldwide Marriage Encounter weekend presentation on "Matrimonial Spirituality" in the 1970's and 1980's follows the Magisterial teaching on the domestic Church focussing on the four marks of the whole Church; One, Holy, Catholic and Apostolic. This model may be applied readily to the spirituality of the family but it is not easy to recognise "windows on the truth" from this perspective. In spite of the teaching there is still some theological debate about whether the Church can

32 A. Lilles, Marriage, Prayer and the Cross, available from http://rcspiritualdirection.com/ blog/2013/08/19/marriage-prayer-and-the-cross-part-i-of-iii, 2012-2013 (17.12.2013).

33 John Paul II, The Theology of the Body: Continence Protects the Dignity of the Conjugal Act, General Audience 24 1979-1984, October 3, 1984, "L'Osservatore Romano”, p. $312 \mathrm{ff}$.

34 DVD based resource: "Home is a Holy Place", Bishops Conference of England and Wales, 2008.

35 J. E. Rotelle (Ed), Augustinian Spirituality and the Charism of the Augustinians: Sacramentum Caritatis as the foundation of Augustinian Spirituality, Villanova 1995, Augustinian Press, p. 45ff. 
be considered a family ${ }^{36}$. It suggests that there needs to be a more pragmatic and robust way of presenting marital spirituality.

Kathy Heskin brought out the comparisons of marriage with the Triduum.

- Holy Thursday asks the couple, "What does it mean to wash one another's feet?"

- Good Friday asks, "How do we prepare for the difficult times that will come to us?"

- Holy Saturday asks, "How do we hold each other when our hearts are breaking?"37.

The liturgy can be shown to have three sources in the Sacramental economy, the Father, source and goal; Christ's work; and the Holy Spirit. As we can say that the liturgy is for the benefit of all the faithful we can add community and describe all four as characteristics of the Sacraments. The analysis below includes some personal examples of the writers' experiences to illuminate the explanations given.

\section{Characteristics of the Sacraments ${ }^{38}$}

3.1. The Primacy of God's Action in creative love is the call to unity in the married and mirrors the communion of love between God and all His people.

36 T. Knieps-Port le Roi, The Domestic Church, in: T. Knieps-Port le Roi - g. Manion - P. DE Mey, The Household of God and Local Households: Revisiting the Domestic Church, Leuven 2013, Peeters, p. 14-15.

37 K. \& N. Heskin: reported by B. Sittler, Married Life said to parallel the Paschal Mystery, in Prairie Messenger, available from http://www.prairiemessenger.ca/04_21_2010/married_04_21_10. html (19.12.2013).

38 Paul VI, Encyclical Letter Humanae Vitae (1968), 25, "While the Church does indeed hand on to her children the inviolable conditions laid down by God's law, she is also the herald of salvation and through the sacraments she flings wide open the channels of grace though which man is made a new creature responding in charity and true freedom to the design of his Creator and Saviour, experiencing too the sweetness of the yoke of Christ". available from http://www.vatican.va/holy_father/paul_vi/ encyclicals/documents/hf_p-vi_enc_25071968_humanae-vitae_en.html (17.12.2013); John Paul II: Apostolic Exhortation Familiars Consortio (1981), 34, "It will be easier for married people to make progress if, with respect for the Church's teaching and with trust in the grace of Christ, ----- they are able to discover and experience the liberating and inspiring value of the authentic love that is offered by the Gospel and set before us by the Lord's commandment". available from http://www.vatican. 
God's love never abandons his people and continues throughout their vulnerability. He loves them so that they experienced affirmation and freedom ${ }^{39}$ and this is the vocation of married couples ${ }^{40}$. Couples are called to love one another so that they build each other up, helping each other to grow as a person and experience transcendence. It also calls them as parents to do the same for their children ${ }^{41}$ and it manifests itself in the little ways that couples do things for each other; the daily kindnesses, forgiveness, the healing of hurts and realisation that reconciliation is always possible.

3.2. The Centrality of Jesus. "I am the Way, the Truth and the Life" ${ }^{42}$. Christ is the guide to couple spirituality, their way to God. The more the married couple can mirror Christ's love for His Church the more they symbolise the mission of the Church and the more they can, "achieve ecclesial unity through the spiritual and practical orientation of one's life with regard to Christ" ${ }^{43}$. In Ephesians 5, St. Paul calls the married to a sacrificial love that is best understood by looking at the way Jesus lived in the final period of his life.

3.3. The Presence of the Holy Spirit is the couple's means of fulfilling their vocation ${ }^{44}$. Without the Holy Spirit they cannot hope to succeed. They need the power of his love to take them through the good and bad periods of life. When

va/holy_father/john_paul_ii/apost_exhortations/documents/hf_jp-ii_exh_19811122_familiarisconsortio_en.html (17.12.2013).

39 R. Miggelbank, Theological Perspectives on Marriage in Postmodern Times, "INTAMS Review" Vol 14, (Spring 2008), p. 48.

40 John Paul II, Apostolic Exhortation Familiars Consortio (1981), 12, “The communion of love between God and people, a fundamental part of the Revelation and faith experience of Israel, finds a meaningful expression in the marriage covenant which is established between a man and a woman". available from http://www.vatican.va/holy_father/john_paul_ii/apost_exhortations/documents/ hf_jp-ii_exh_19811122_familiaris-consortio_en.html (17.12.2013).

41 John Paul II, Apostolic Exhortation Familiars Consortio (1981), 72, “... by virtue of the fact that marriage is a sacrament, confers upon Christian married couples a special mission as apostles, sending them as workers into his vineyard, and, in a very special way, into this field of the family in this activity...." available from http://www.vatican.va/holy_father/john_paul_ii/apost_exhortations/ documents/hf_jp-ii_exh_19811122_familiaris-consortio_en.html (17.12.2013).

42 John 14:6.

43 R. Miggelbank, Theological Perspectives on Marriage in Postmodern Times, "INTAMS Review" Vol 14, (Spring 2008), p. 51.

44 John $14: 26$. 
they are in conflict, the Holy Spirit provides the strength they need to persevere, to have patience ${ }^{45}$, to not give up on each other and to approach their family issues as a couple, for example when a child has gone astray.

3.4. Community in which the couple lives out their vocation. Within our family, community is beautifully expressed in the video published by the Bishops of England and Wales, "Home is a Holy Place" ${ }^{46}$. True love reaches out beyond itself to the rest of the Church, the neighbourhood, the workplace and where witness as a married couple is an image of Christ's love for all of creation ${ }^{47}$. It's where married couples are called to witness God's love for them, and Christ's love for his Church ${ }^{48}$.

\section{The Centrality of Jesus}

The most powerful image of love that we have is the sacrificial love of Our Lord Jesus Christ in the last week of His life on Earth. It is His experiences during Holy Week that provide a paradigm for spirituality to which the married can relate.

\subsection{Palm Sunday ${ }^{49}$}

The Triumphal entry of Jesus into Jerusalem that is celebrated on Palm Sunday is mirrored by the celebrations in married life, firstly the wedding celebration and then by the many other celebrations the couple enjoys; Christmas, Easter, birthdays, family successes, the celebrations of the wider family and the family of the Church. Ray, who was not a Catholic at the time, had apprehensions about the wedding

45 Catechism of the Catholic Church nn 2003: The sacramental graces of the Holy Spirit, London 2003, Burns \& Oates.

46 Bishop's Conference of England \& Wales, Home is a Holy Place (2008) Video resource available from http://www.homeisaholyplace.org.uk/ (19.12.2013).

47 John Paul II, Apostolic Exhortation Familiars Consortio (1981), 71 “--- it is especially necessary to recognise the unique place that, in this field (Community) belongs the mission of married couples and Christian families, by virtue of the grace received in the Sacrament (of Marriage?). -------- In this activity, married couples act in communion and collaboration with the other members of the Church". available from http://www.vatican.va/holy_father/john_paul_ii/apost_exhortations/ documents/hf_jp-ii_exh_19811122_familiaris-consortio_en.html (17.12.2013).

48 Ephesians 5:21-33.

49 John 12:12-17. 
celebration, concerns about the nature of the commitment he was making and whether the arrangements he and Elizabeth had made would be successful, but nevertheless enjoyed the day very much. Jesus of course knew His destiny and must have had apprehensions and concerns but still enjoyed His moment of triumph.

\subsection{Jesus Drives the Merchants Out of the Temple ${ }^{50}$}

There is a danger that the demands of work, commitments to outside activities and the retaining of old friends, particularly if they are not married will reduce the time a couple has for spiritual input, that is simply being with and for each other, to such a small part of their lives that tension builds up. Both of us had to learn to not make commitments either for ourselves or for both of us without consulting each other. This we came to understand and articulate as "always having a prior commitment". We had to learn to put each other first and recognise and oppose the divisive nature of the world around us that still wanted to treat us as uncommitted individuals.

Couples need to take notice of the action of Jesus in clearing out the temple of all that is not of God. The western culture of individualism creates much tension in marriage and needs to be cluttered out so that the couple can grow spiritually.

There have been numerous times that we have had to re-evaluate what is going on in our lives and if necessary make changes. An example is the time early in our marriage we went for a long walk and realised that we both had a closet dream of working for those less well off in the third world countries. We made a decision and changed our lives so that we could give 2 years to the mission in Papua New Guinea. This has had the effect of changing the way we look at material goods as well as our own mission in life.

\subsection{Render unto Caesar ${ }^{51}$}

There is a Christian duty to obey secular law in so far as it not in conflict with Catholic teaching. Both Ray and Elizabeth found many and surprising sources of compromise that at times made us feel uncomfortable. For Elizabeth it was being coerced into rejecting patients for counselling who presented issues that might not give the practice satisfactory results for success statistics. For Ray it was being

\footnotetext{
50 Mt $21: 12-17$.

51 Mt 22:15-22.
} 
pressurized into reporting problems on a large project in a way that reflected positively on the company for which he was working. Though neither example was directly related to our relationship they both had deep negative effects on our preoccupation with outside influences that resulted in tension between us.

Couples need to support each other in recognising and rejecting influences from the secular world that impinge on their life of faith. This takes courage in the face of friends or even family who reject the teachings of the Church and may criticise and be divisive in attacking either husband or wife thus creating pressure to compromise.

\subsection{Holy Thursday ${ }^{52}$}

Christ washed the feet of his disciples. Husband and wife wash each other's feet daily when they put aside something they want to do in order to do something their spouse asks of them.

Ray is a worrier, and he will sometimes wake in the middle of the night disturb me and I know that I have to listen to him instead of trying to go back to sleep. I may have plans for the day but Ray is under pressure and needs me to do something to help him. We may drop a plan to see to the needs of the children, even as they grow older. Our older daughter is disabled and, through psychological problems emanating from her early childhood before we adopted her, is very vulnerable. Normalising our reactions to her constant need for support involves washing each other's feet as we try to find common ground on how to deal best with almost daily crises.

I, Ray, am rather stoic about illness, seeing it as being a fight between me and a problem that I don't want Elizabeth to be involved in. Elizabeth, on the other hand, likes to be visited regularly and comforted in her illness. This is alien to me but I wash her feet by tending to her needs rather than following my instinct to leave her to get on with it. At one level I am extremely anxious about any ill health she has but at the same time I want to be seen as strong and reassuring. Being vulnerable to Elizabeth about my reactions is very difficult but it is the therapy she needs.

At the Last Supper Jesus communed with His friends and shared with them His very self in the form of bread and wine. Spouses commune with each other at meals when they share hopes and fears and enjoy the company of each other in the

52 John 13:2-15. 
relaxing atmosphere of the table. By extension this communing is also important for family spirituality as the whole family share with each other at a common table.

\subsection{The Agony in the Garden ${ }^{53}$}

At a time of great fear and stress in His life Jesus prayed in the Garden of Gethsemane to be relieved of His burden and then accepted His fate. Prayer is an important part of our life as a couple especially when the demands of family and Ray's ministry as a deacon lead to stress in our relationship. We have also had to grow into being vulnerable in prayer at the end of each day by bringing our individual, and couple fears before each other and God. It enables fear to be replaced by strength and a willingness to start the new day afresh. Prayer is a time when we can heal hurts small and large which occur during the day. It's when we turn to each other and say we're sorry; when we imitate the Lord's prayer of submission to His Father, "Thy will be done".

\subsection{Betrayal $^{54}$}

Jesus was betrayed by Judas, His disciple, at Gethsemane. At times of stress, either from external forces or from internal misunderstandings, spouses can experience anger and loss of temper. These are times of betrayal in which spouses share the distress of disunity.

\subsection{Good Friday ${ }^{55}$}

Jesus knew the gift He was making of Himself in sacrificing His life for us. In marrying, husband and wife make a gift of themselves to each other. No one would think of giving a wrapped gift to their loved one without knowing what it contains. This is the driving force behind the need for self-discovery. The making sacred of our love is the giving of myself to Elizabeth in complete vulnerability. Here I am, known to you as much as I am known to myself. It is a sacrifice for me to share my deepest fears and hopes with Elizabeth, and sometimes very difficult when I am not fully aware of what those hopes and fears are. Christ's gift was His

53 Mt 26:36-46.

54 Mt 26:49.

55 John 19:28-30. 
very self and I am called to give myself to Elizabeth in the same way. The gift of me is the greatest thing I can give to Elizabeth and this requires me to search deeply for self-knowledge. I understand this not so much in terms of deep psychological analysis but as the fruit of discovering who I am before God. In understanding myself to be the created, literally God's creature, I can move towards the humility needed to have a proper perspective of myself. This is the self that Elizabeth wants to encounter, the real Ray.

My Cross is that of true self knowledge and the willingness to share myself with Elizabeth. This is most difficult for me in the areas of faith, illness and death. I see Elizabeth as a much holier person than I am, I want my illnesses to be personal rather than a shared battle and I am afraid of death, my cry being, "Lord give me more time".

We sacrifice too in the most vulnerable way in our sexual relationship. At its best sex is a true sacrifice of our self for the sake of the other and it can be said that the marriage bed is our altar of sacrifice.

I was in the habit of leaving decisions to Ray, discussing problems with him but the final choice had be his to carry out. When we discovered that we could not continue fostering two children we had taken on I wanted Ray to make the final decision and telephone the social services. He was undergoing his own crisis, he broke down and cried. Taking responsibility was hard for me but out of love for Ray I had to make the decision of what to do and carry it through myself.

When Ray had been asked for the third time to become a deacon I realised that I would have to let go and believe that this was what God wanted for us. I now had to share Ray with a wider group of people. It has called us both to recognise that we sacrifice not only for each other but for those to whom we minister but the sacrifice has always to be in the context of our first call to unity with each other.

Many of our Good Fridays also have to do with our adopted children; one older daughter is now in a wheel chair and has suffered from abusive relationships. She has been married outside the Church three times and her five children have been removed from her care. We are now her part time carers, although she is living independently in a customised flat. 


\subsection{Holy Saturday ${ }^{56}$}

The Church waits for Christ to return from opening the gates of heaven for the just. Waiting is so much part of our lives as a couple. When we were first married Ray was not a Catholic. He came to Mass with me after a plea one Sunday morning soon after we were married; I said I was lonely at Mass without him. For the first six years of our marriage I would touch his shoulder after receiving Holy Communion. I was afraid to ask him to become a Catholic in fear of pushing him away from the Church. I waited anxiously but patiently until, after our Marriage Encounter weekend he was received into the Church.

I have also experienced times of trauma, when waiting outside of an operating theatre, or when he is late arriving home. We wait also for our children to grow in faith and understanding of what is going on in their lives.

Elizabeth is a very talented lady. I have always known this; I recognised it the first time I met her and yet for many years she saw herself as not having special gifts, only determination and grit. Her early education was interrupted by some time spent in Australia and when she was accepted for teacher training it was on the basis that she was an experimental student, not as well qualified as her peers. This sense of inferiority stuck with her until 1995 when I had just finished my Master's Degree. We were introduced as speakers at a conference on Augustinian Spirituality; I was given a big build up about my dissertation and then Elizabeth was introduced simply as my wife. She was so angry at being seen just as an appendage to me that she reacted by taking a Master's Degree herself.

As a result she reawakened an interest and took a First Degree in psychology and would have liked to have continued to become a clinical psychologist but ran out of years before retirement and so took a shorter course to become a counsellor. Her greatest personal talents are her ability to sense distress in people and tremendous listening powers. We were married for nearly thirty years before her light was fully uncovered and it has been a joy to me that others can now fully appreciate what I have always known about her.

After my ordination as deacon I started to say that I did not want Elizabeth to be known as the wife of the deacon but for me to be known as the husband of the therapeutic counsellor. To me this shows the respect and dignity she deserves.

56 John $20: 18$. 


\subsection{Easter Sunday ${ }^{57}$}

The word that best describes my experience of the resurrection of Jesus is transcendence. Because of Elizabeth's love of me and the strength of our relationship I have been able to overcome my deep shyness and give talks on many subjects over the years. Although I had wanted to be of service to the Church for a long time I had no thoughts about becoming a deacon and would not have been able to accept the challenge without Elizabeth's support.

The gap between what little I see myself as having to offer and what I have been able to do has been filled by the Holy Spirit working in us both as a result of our Sacramental commitment to each other. I now reject the saying that God fits the burden to the back. He calls us to do the work that needs to be done and we are empowered by the Holy Spirit to fill the gap between that call and that of which we believe ourselves capable.

Together we experience transcendence in the work we do both together and separately. In this we are freed from the negativity and death that comes from failure, disappointment and disillusionment. Life has been and still is an adventure and we still look for new ways in which we can be of service to the Church.

For me the great joy in being married to Ray is that I believe that I have become more the person God created me to be than I could ever have become without him. Our life has been an adventure in which we are still exploring new ways of being together and experiencing God's love for us. We have witnessed over the years the effect of our "couple power" 58 in the life of the Church and in our family life.

Soon after Ray asked me to marry him, I said that I thought I should wait for a while till my Mum had recovered from my Dad dying. Ray said that we could support her together. I know that marrying was the right decision as we are still caring for Mum in a way that has given her a freedom to be herself and has brought me growth and a full life. I might have been buried alive and never emerged if I had not married as Mum is still alive 44 years later and is suffering now from Dementia and in much need of our ministry to her.

\footnotetext{
57 John 20:1-18.

58 Worldwide Marriage Encounter weekend presentation, “Sacrament”, 1980’s.
} 


\subsection{The Sweetness of the Yoke of Christ ${ }^{59}$}

Sacrifice is the sigh of the love of Jesus for us and it is that spirit of love that can fill our relationship. Holiness is present in the way we love one another through the messiness of life and in marriage we ask God to bless these moments. Therefore holy is what we are when we love one another through good and bad times and that holiness is what we bring to our family, and to others. It is a mistake to identify holiness with perfection just as it is a mistake to hear Jesus in Matthew's Gospel giving us a commandment "You must therefore be perfect just as your heavenly Father is perfect"60. Read as a commandment the achievement of perfection can only at best be a fleeting moment. Aquinas defines perfection as, "that which lacks nothing"61, a condition surely that can only be achieved by God. Mt 5:48 is call to holiness that is the ultimate goal of the Christian life that is experienced by the married in their striving for unity.

\section{Marital Spirituality, the Centre of Family Spirituality}

To paraphrase G K Chesterton's aphorism about Christianity, “The Marriage ideal has not been tried and found wanting. It has been found difficult; and left untried" ${ }^{\prime 2}$. The fundamental unity that married couples are called to is of mind and heart, a parallel to the unity that exists within the Blessed Trinity, such that each become the agent of the other's salvation. It is both spiritual and mystical and embraces a vast spectrum of experiences derived from the uniqueness of the

59 Paul VI: Encyclical Letter Humanae Vitae (1968), 25, "And now We turn in a special way to Our own sons and daughters, to those most of all whom God calls to serve Him in the state of marriage. While the Church does indeed hand on to her children the inviolable conditions laid down by God's law, she is also the herald of salvation and through the sacraments she flings wide open the channels of grace through which man is made a new creature responding in charity and true freedom to the design of his Creator and Saviour, experiencing too the sweetness of the yoke of Christ". available from http://www.vatican.va/holy_father/paul_vi/encyclicals/documents/hf_pvi_enc_25071968_humanae-vitae_en.html (17.12.2013).

60 Mt $5: 48$.

61 Thomas Aquinas, Summa Theologica, Pt II-II, Q 184, second Art.

62 G. K. Chesterton, What's Wrong with the World: The Unfinished Temple, USA 2009, Seven Treasures Publications, Part I, Ch. 5. 
two individuals and their relationship. It is a challenge for those with the faith, maturity, determination and willingness to embrace what can be a great adventure; marriage is not a solution or an answer to any question.

Marital spirituality is holistic. It cannot be simply defined by the practice of religious piety though that is proper to married couples. Neither can it be confined to the search for spiritual meaning in each individual. Prayer, Penance and the Eucharist are major influences in the spiritual life but these are common to all forms of life, to the unmarried as well as the married. Rather, married couples are searching for their spirituality, their window on the truth, in the context of their relationship. Marital unity is defined in that framework. It encompasses the whole of each couple's relationship, the messy and unpleasant events as well as the joyful and celebratory occasions that can best be expressed through Christ's experiences of Holy Week.

"The formative experience of family is core to each individual's identity. Even in senior years, reflection on 'who I think I am' inevitably includes reflection on the formative influences in my life, generally understood to be most powerful during the impressionable years of childhood. If it is true that family plays a major role in shaping each one of us then family requires the most careful attention by both society and church"63.

Striving for unity has as its first goal the salvation of the two spouses. Together they reach out to their children and, through their demonstration of what covenanted love is, show an image of the love of Christ for the whole Church and in particular the little or domestic Church of which children are a part ${ }^{64}$.

"Above all else, spirituality is about our relationship with God. The word we use to modify 'spirituality' tells us the principal way we experience that relationship. A monastic spirituality is one that finds God in the silences, the prayer rituals, the work and discipline of the monastery. An ascetic spirituality relies heavily on denial, while a 'spirituality of the market place' seeks God in ministry. A family spirituality experiences God in and through the ordinary relationships and events of family life. This way of life becomes the principal means for knowing God, the primary source of grace and holiness for those called to this particular religious

\footnotetext{
63 Catholic Bishops' Conference of England and Wales, Not Easy But Full of Meaning,

Catholic Family Life in 2004, Hampshire 2005, Redemptorist Publications, Foreword 1.

64 Pope Francis, Encyclical Letter Lumen Fidei 53 (2013); "In the family, faith accompanies every age of life, beginning with childhood: children learn to trust in the love of their parents", Vatican Press 2013.
} 
vocation. The simple tasks of bathing, feeding, storytelling and playing with children, all become sacramental when we understand sacraments as outward signs of our relationship with God and that relationship as incarnated in family. The more difficult tasks of letting go, welcoming the people our children choose into the circle we have created, caring for the aged with the pain it brings, all become passion and resurrection, when we recognize them as ways of laying down our lives for the other" ${ }^{35}$.

The couples call to love is therefore the centre of the family which can be seen through the vision of the family expressed in "Home is a Holy Place"66.

- Home is a holy place because God is present there is love.

- Home is a holy place because relationships within the family reflect God's relationship with us.

- Home is a holy place because God's presence graces all creation.

These three visions of the holiness of family life can best be nurtured by the spirituality of the couple, although this vision can and is lived out by many families who do not have a Sacramental married couple at the hub but have a person or persons in relationship with God.

\section{Bibliography}

Aquinas T., Summa Theologica, Christian Classics, Maryland 1948.

Catechism of the Catholic Church, Burns \& Oates, London 2003.

Catholic Bishops Conference of England and Wales, Home is a Holy Place, DVD based resource, 2008.

Catholic Bishops Conference of England and Wales, Not Easy but full of Meaning. Catholic Family Life in 2004, Redemptorist Publications, Hampshire 2005.

Chesterton G. K., What's Wrong with the World: The Unfinished Temple, Seven Treasures Publications USA, 2009.

de Chardin P. T., Le Phénomène Humain: Editions du Seuil, Paris 1956.

65 K. O'Connell Chesto, Being Home When God Comes. National Catholic Reporter. 15.11.02, in: Not easy but full of Meaning, Catholic Bishops of England and Wales, Hampshire 2005, Redemptorist Publications, p. 42.

66 Marriage \& Family Life Project Office, Introducing Home is a Holy Place, Surrey 2008, Wellington Press, p. 5. 
Gallardetz R., A Daring Promise: A Spirituality of Christian Marriage, Ligouri/Triumph, Ligouri, Missouri 2007.

Knieps-Port le Roi T. - Manion G. - DE Mey P., The Household of God and Local Households: Revisiting the Domestic Church, Peeters, Leuven 2013.

Knieps-Port le Roi T. / Sandor M. (eds.), Companion to Marital Spirituality: Peeters, Leuven 2008.

Lilles A., Marriage, Prayer and the Cross, 2012-2013, Internet resource.

Miggelbank R. Theological Perspectives on Marriage in Postmodern Times, "INTAMS Review" Vol 14, Peeters, Leuven 2008.

Rotelle J.E. (Ed.), Augustinian Spirituality and the Charism of the Augustinians: Sacramentum Caritatis as the foundation of Augustinian Spirituality, Augustinian Press, Villanova 1995.

Sittler B., Reported Kathy \& Neil Heskin, in: Married Life said to parallel the Paschal Mystery, in: Prairie Messenger, USA, 2010.

The Divine Office, Vols I-III, Collins, London 1974. 